\title{
민주주의와 국제개발협력
}

- 한국의 민주화 경험과 ODA -

이 성 훈 한국인권재단 상임이사

\section{목 차}

\section{I. 들어가면서}

1. 부산총회의 역사적 배경과 맥락 - 민주적 거버넌스의 관점에서

2. 민주주의 국제협력 담론과 특성

3. 민주주의와 국제협력 : '개발독재' 와 '민주적 개발'

4. 한국의 사회발전 - 해외원조의 역할

5. 한국의 사회발전 경험과 개발원조 모델

6. 한국의 ODA 정책에 대한 함의와 제언

\section{II. 결 론}

\section{I. 들어가면서}

올해 11월 말 부산에서 열리는 OECD 세계개발원조총회(이하 부산총회)를 앞두고 한국의 개발경험 과 개발원조에 대한 국제사회의 관심이 다시 높아지고 있다. 사실 국제사회의 한국 경제개발 경험에 대한 관심은 새로운 것은 아니다. 그러나 최근의 관심은 작년 11 월 서울 G20 정상회의와 올해의 부 산총회를 계기로 부상한 것이어서 과거와 차별성을 보이고 있다. 즉 과거의 관심이 한국의 개발 경험 자체에 대한 것이라면 최근의 관심은 그러한 경험을 바탕으로 한국이 국제개발협력 분야에서 어떤 역할을 할 것인가에 초점이 맞추어지고 있다.

잘 알려졌듯이 작년 11월 서울에서 열린 G20 정상회의는 한국정부가 주도한 서울개발컨센서스 (Seoul Development Consensus)를 채택하였다. 서울 회의를 준비하면서 한국정부는 '경제위기 이 후 동반성장(Shared Growth Beyond Crisis)'를 주제로 경제위기 극복과정에서 개도국과 선진국의 가교 역할을 자임하였고 한국의 개발경험을 개도국과 공유하기 위한 지식공유프로그램(Knowledge Sharing Program, KSP)을 적극적으로 강조하고 추진해 왔다. 
작년 G20 정상회의를 계기로 한국정부는 한국형 개발경험을 정식화하고 이를 국제사회 특히 개도 국과 공유하는 것을 주된 화두로 삼았다. 그리고 1 년 후 열리는 부산총회의 화두는 이러한 한국 개발 경험에 대한 이해를 기반으로 하여 국제기준에 부합하는 한국형 개발원조 사업의 모델을 만드는 것 으로 발전하였다.

한국의 시민사회 또한 작년 서울 G20 정상회의를 계기로 한국의 개발경험에 대한 시민사회 관점 에서의 평가 특히 경제개발과 민주화 과정에서의 시민사회 역할에 대해 보다 적극적인 관심을 보이 기 시작하였다. 그리고 부산총회를 계기로 개발원조에서 시민사회의 역할에 대해 본격적인 논의를 전개하고 있다.

본고는 부산총회를 둘러싼 국내외적 맥락에서 한국의 민주화 경험을 공적개발원조(Official Development Assistance, ODA) 사업에 어떻게 연결할 것인가를 다루고자 한다. 이를 위해서 먼저 부산총회의 역사적 배경을 개발과 민주화의 관점에서 개관하고 개발과 민주주의의 개념과 이를 둘러 싼 담론을 간략히 정리하고자 한다. 그리고 이를 토대로 한국의 개발과 민주화 경험에 대한 해석을 개발원조와의 연관시켜서 살펴보고자 한다. 마지막 결론에서는 이러한 논의가 한국정부의 개발원조 정책에 지니는 함의와 정책 제안을 제시하고자 한다.

\section{1. 부산총회의의 역사적 배경과 맥락 - 민주적 거버넌스의 관점에서}

잘 알려졌듯이 부산총회는 2005 년의 제 2 차 세계개발원조총회가 채택한 파리선언 이행을 평가하고 이후 개발원조의 방향을 모색하는 역사적 회의이다. 그러나 부산총회가 열리는 2011년 말의 국제 정 치 및 경제적 맥락은 6년 전 2005년 파리회의에 비해 큰 차이를 보이고 있다. 지구적 식량 및 에너 지 위기, '아랍의 봄'과 미국과 유럽의 금융위기 등 개발을 둘러싼 외부 환경의 변화는 민주화 또는 민주주의와 개발 담론과 정책에 적지 않은 영향을 주고 있다.

첫째, 2000 년대 중반 위기 가속화되고 있는 식량과 에너지 위기 등 개도국 개발환경의 악화이다. 지난 2010년 유엔의 MDGs 10년 이행평가에서 드러났듯이 국제사회가 합의한 개발목표인 MDGs의 이행 가능성은 현재 매우 어렵다는 것이 중론이다. 국내적 개발정책의 낮은 효과성과 거버넌스의 실 패, 공정하지 않은 국제 무역과 금융정책으로 인한 안정적인 개발정책 추진의 어려움 등 국내외적 요 인들이 주된 원인으로 지적되고 있다. 이러한 맥락에서 개도국의 구조적 가난과 불평등의 원인으로 신자유주의 경제정책에 대한 비판의 목소리가 높아지고 있다.

둘째 '아랍의 봄'으로 지칭되는 작년 말 이후 중동과 북아프리카의 민주화 운동이다. 중동과 북아 프리카의 민주화는 과거 한국과 다른 지역에서 나타났듯이 인권과 민주주의 진전없는 경제개발이 얼 마나 취약한지 분명하게 보여주었다. 즉 민주주의는 단순한 양적 경제성장의 결과로 저절로 주어지 는 것이 아니기에 민주화와 경제개발의 동반성장 필요성과 민주적 거버넌스의 중요성을 다시 일깨워 주었다. 
셋째, 2008년 말 미국발 경제위기와 유럽으로 확대되는 있는 금융, 채무 위기는 금융부분의 민주 적 거버넌스 중요성을 상기시켜 주고 있다. 국제개발협력에서 서방 공여국은 모범적 거버넌스(good governance)를 강조해왔다. 그러나 정작 자신들의 금융 정책에서는 거버넌스의 핵심 원리인 투명성 과 책무성을 제대로 시행하지 않았다는 것이 이번 사태를 계기로 드러났다. 금융위기를 계기로 출범 한 G20 정상회의는 이러한 맥락에서 국제통화기금(IMF) 지배구조 개혁과 투명성에 대한 강조를 하 고 있다.

넷째, 부산 총회의 주 의제가 원조효과성에서 개발효과성으로 확대되면서 개발효과성을 위한 민주 적 거버넌스의 역할이 다시 부각되고 있다. 개발효과성에 대한 논의는 자연스럽게 원조와 개발체제 (Aid and Development Architecture)와 패러다임에 대한 논의로 연결되는데 이 과정에서 국제적 차 원에서 민주적 거버넌스의 역할이 다시 강조되고 있다. 특히 이러한 논의는 내년 6월 브라질 리우에 서 열리는 유엔지속가능개발회의(리우+20)과 2015년 이후 밀레니엄개발목표(MDGs)의 미래를 둘러 싼 논의의 맥락에서 더욱 본격적으로 전개될 것으로 보인다.

위에서 언급한 맥락과 배경에 따르면 부산총회는 기존의 원조효과성에 대한 논의의 마무리이자 개 발효과성 관련 민주적 거버넌스에 대한 논의의 본격적인 출발점이라고 할 수 있다. 이러한 국제적 논 의의 맥락에서 한국의 개발경험을 민주화의 관점에서 재해석하는 것은 국제개발협력에서 계속 높아 지는 한국의 위상과 비중을 고려할 때 매우 중요하다고 판단된다.

\section{2. 민주주의 국제협력에 대한 담론과 특성}

민주주의가 국제협력의 분야로 등장한 것은 최근의 일은 아니다. 이미 미국은 50 년대부터 민주주 의 증진을 외교의 목표로 설정하고 다앙한 제도와 정책을 통해 국제적으로 민주주의를 확산시켜왔 다. 그러나 냉전시기 유엔 내에서 민주주의는 정치적 민감성과 주권 우위의 논리에 눌려 주된 의제로 다루어지지 않았다. 그러나 몇몇 개별 국가의 노력은 80년대 냉전 말기와 90 년대 탈냉전 시기에 접 어들면서 국제기구의 적극적 참여와 주도로 세계적으로 확산 및 제도화되는 추세를 보이고 있다. 즉 과거 서구 자본주의 국가를 중심으로 진행되어 왔던 '민주주의 지원'은 오늘날 '민주주의 국제협력'이 라는 패러다임으로 자리잡아 가고 있다.1)

국제적 차원에서 민주주의를 국제협력 분야에서 의제화하고 제도화하려는 시도는 1986년 마닐라 에서 첫 출범한 신생재건민주주의국제회의(ICNRD)이다. 유엔 주도로 열린 이 회의는 80년대 냉전 시대 국가안보와 경제발전의 논리에 간과 또는 희생되어온 민주주의의 중요성을 부각시키는 역할을 하였다. 90년대 탈냉전 시대를 맞이하여 1995년 스웨덴의 주도로 선거를 통한 민주주의의 제도화와 강화를 목적으로 국제기구로 출범한 민주주의 선거지원 국제연구소(IIEDA), 1997년 국제의원연맹

1) 이정옥 편 “민주주의 국제협력기관: 지구민주화와 공공외교의 지형도” (민주화운동기념사업회 편, 리북 2010) '반세기 동안 거듭 발전한 해외민주주의 지원과 해외 민주주의지원을 어떻게 바라볼 것인가' (30-42쪽) 참조 
(IPU)의 세계민주주의선언 채택 등 민주주의를 의제화 및 제도화 하려는 다양한 국제적 노력이 가시 화되었다.

이러한 노력은 2000년에 바르샤바에서 창립 총회를 갖고 출범한 민주주의 공동체(Community of Democracies $\mathrm{CoD}$ )에서 보다 본격화되었다. 미국 주도의 다자간 민주주의 협력체인 민주주의 공동체 는 이후 2004년 유엔 내부 특히 인권위원회와 유엔 총회에서 민주주의 의제를 확산하는 발판 역할을 하는 민주주의 코커스(Democracy Caucus)의 출범으로 이어졌다. 이러한 흐름에 힘입어 유엔 인권이 사회와 유엔 총회는 매년 민주주의에 관한 결의안을 채택해왔다. 이러한 노력은 2005년 유엔 새천년 5 주년 정상회의의 결의안에 따라 사무총장이 직접 관할하는 유엔민주주의기금(UNDEF)의 탄생으로 이어졌다. 그리고 유엔 총회는 2007년 9월 15 일을 민주주의의 날로 지정하는 결의안을 채택하였다.

한편 유엔에서 개발을 담당하는 유엔개발계획(UNDP)는 민주적 거버넌스(Democratic Governance) 프로그램을 통해 개발과 민주주의에 대한 통합적 접근을 시도해왔고 인권에 기반한 개발에의 접근 (Human Rights-based Approach to Development HRBA)를 적극적으로 도입하였다. 2002년에는 인간발전보고서(Human Development Report, HDR)의 주제로 민주주의 심화를 다루어 개발에서 민 주주의의 중요성을 강조하였다.

이러한 민주주의 확산 흐름은 아시아에서 정부간 협력의 주요 의제가 되어 한국과 인도네시아 정 부의 구체적 시도로 나타났다. 한국정부는 2008 년 아태지역 12 개 국가가 참여한 제 1 차 아태 민주주 의 협력체(Asia Pacific Democracy Partnership, APDP) 고위급 회의를 개최하였고 인도네시아 정 부도 2008년 발리에서 대통령이 직접 참석하는 민주주의 포럼를 개최하였다. 발리민주주의포럼(Bali Democracy Forum, $\mathrm{BDF}$ )를 계기로 과거 동남아시아에서 군사독재와 인권 '후진국'으로 평가받던 인 도네시아는 민주주의를 외교정책의 주요 의제로 설정하고 민주주의 선도국가로 국제적인 이미지와 위상을 변화를 시도하고 있다.

앞에서 간단히 살펴보았듯이 이제 민주주의는 선언문에 언급되는 가치를 넘어서서 국제질서를 움 직이는 하나의 축으로 자리잡았다. 민주주의가 국제협력의 중요한 의제로 등장하면서 자연스럽게 개 발, 인권, 평화 등 다른 분야 국제협력과의 연관성에 대한 관심이 높아지고 있으며 민주주의와 개발 관련한 담론 또한 변화 발전하고 있다. 정책과 사업 차원에서는 권력을 감시하는 시민사회 역량과 리 더십 강화, 투명성과 책무성 증진, 인권보호와 증진 제도(인권 거버넌스), 법치, 언론자유, 자유롭고 공평한 선거, 독립적인 사법기구 등 민주적 거버넌스(Democratic Governance) 관련한 다양한 이슈 를 다루고 있다.

이러한 과정에서 민주주의 분야 국제협력에서 몇 가지 특성이 드러나고 있다.

첫째, 주권에 대한 이해의 변화이다. 과거에는 특정 국가에 대한 민주주의와 인권운동에 대한 지 원을 둘러싸고 내정간섭이자 주권침해라는 논란이 일었다. 그러나 오늘날 유엔이 2005년 채택한 국 제사회의 인권 보호책임(Responsibility to Protect, R2P)의 원칙에서 나타나듯이 주권은 배타적인 국가의 권리가 아니라 국민의 인권보호 책임과 연관시켜 이해하는 경향이 강화되고 있다. 즉 주권에 
비해 상대적으로 민주주의와 인권 등의 보편적 가치의 중요성이 더 강조되고 있다.

둘째 경제성장을 통한 민주주의에 대한 간접 지원에서 민주주의 증진을 위한 직접 지원으로의 정 책 변화이다. 과거에는 경제발전 등의 외부요인을 지원을 통해 민주주의 증진을 간접적으로 도모해 야 한다는 입장이 우세하였다. 그러나 경제발전이 민주화로 이어지지 않는다는 경험적 사례가 많아 지면서 민주주의를 직접 지원해야 한다는 입장이 강화되었고 민주주의는 국제협력의 주요 축이자 사 업 분야로 자리잡아가고 있다.

셋째 민주주의와 개발, 민주주의와 인권, 민주주의와 평화 등 민주주의에 대한 통합적 인식이 확 산이다. 민주적 개발, 민주주의에 대한 권리, 민주평화론 등 민주주의를 핵심적인 가치이자 프레임 으로 국제협력을 이해하고 증진하고자 하는 시도가 다각도로 이루어지면서 이에 대한 이론적 정책적 연구도 활성화되고 있다.

넷째, 민주주의 국제협력의 공적 차원과 초당파적 성격이다. 사회개발 사업에 비해 민주주의는 민 간단체 보다는 정부기구나 정부 설립 공적재단을 통한 국제협력이 우세하며 특정 정당보다는 좌우를 넘어서는 공통의 가치로 보수와 진보적 성격의 모든 정당이 참여하는 특성을 보이고 있다. 이는 민주 주의가 지닌 공적 성격에서 기인하는 것으로 민주주의가 특정 정치적 이념이 아닌 보편적 가치로 수 용되고 있기 때문이기도 하다.

\section{3. 민주주의와 개발 담론 - '개발독재' 와 '민주적 개발'}

국제적으로도 학계와 국제기구 및 시민사회에서 발전과 사회발전 개념 자체 그리고 사회발전과 민 주주의의 관계에 대한 다양한 논의가 전개되어 왔다. ${ }^{2}$ 서두에서 언급했듯이 국내에서 작년 G20 정 상회의를 계기로 '한국형 개발모델', 올해의 부산 총회를 계기로 ‘한국형 원조 모델'란 말이 자주 사용 되고 있다. 과연 ‘한국형’이란 표현을 붙일 만큼 독특하고 새로운 내용이 있느냐는 원론적인 질문도 있지만 주된 관심은 과연 '한국형'의 주된 내용이 무엇으로 할 것인가에 모아지고 있다.

한편 국내에서는 복지국가 논쟁을 계기로 한국의 개발경험 또는 사회발전에 대해 다양한 관점에서 성찰이 이루어지고 있다. '성장이냐 복지냐'라는 고전적인 쟁점부터 '산업화-민주화-선진화’로의 사 회발전 패러다임, 그리고 주요 정당이 내세운 '한국형 복지국가', '창조적 복지국가', '역동적 복지국 가' 등 한국의 복지 모델을 둘러싼 논의가 경쟁적으로 전개되고 있다.

한국의 사회발전을 설명하는 다양한 이론적 개념과 프레임이 있지만 본고에서는 민주화와 관련성

2) 개발은 영어 Development의 번역어인데 Development은 한국어로 크게 개발 開發 또는 발전 發展으로 번역한다. '경제 개발'과 '경제발전'이란 단어를 혼용해서 쓰듯이 개발과 발전은 분명하게 구분되지 않는 경우가 많다. 이에 비해 사회학 에서는 '사회발전'과 '사회개발'을 구분해 사용하기도 한다. 언어적으로 개발은 타동사 발전은 자동사로 개발이 외부의 개입을 의미하는 타율적 외발적 변화를 의미한다면 발전은 자립적 내발적 변화를 의미한다. 즉 개발은 '다른 사람이 의 도적 계획적으로 개입하여 발전을 촉진하는 행위’라고 말할 수 있다. 본고에서는 사회발전은 정치,경제, 사회적 개발을 포괄하여 사회 전체를 포괄하는 개념으로 사용한다. 1986년 유엔의 발전권 선언은 발전(Development)을 정치, 경제, 사회 및 문화적 측면을 포함하는 과정으로 이해하고 있다. 
이 높은 '개발독재(Development Dictatorship)'와 '민주적 개발(Democratic Development)' 두 개의 프레임을 중심으로 간략히 설명하고자 한다.

먼저 개발독재는 간단히 말해 비민주적인 독재 방식으로 경제개발을 추진하는 것을 의미한다. 개 발독재는 '민주주의 없는 경제개발' 모델로 정치적 자유와 인권의 보장 및 참여민주주의적 제도의 발 전 없이 권위주의적 정부 - 군부 또는 관료 주도의 - 에 의한 경제성장 추구를 특성으로 한다. 역사적 으로는 80년대 중반 이전의 한국과 대만이 대표적이며 군사독재는 아니지만 정치적 권리가 여전히 심각하게 제한되고 있는 싱가포르도 이에 해당하는 것으로 볼 수 있다. 이러한 모델에 따르면 인권과 민주주의는 서구적 가치이고 아시아는 그러한 서구적 가치가 아닌 아시아적 방식 즉 도덕적 권위를 지닌 엘리트에 의한 통치가 적합하고 더 효율적이다. 이른바 '아시아적 가치(Asian Value)'를 합리화 하는 이론이다.

한편 민주적 개발은 개발독재와 반대로 민주적인 방식으로 경제개발을 추진하는 것을 의미한다. 이 모델은 경제개발과 민주화가 상호 배타적인 선택이 아닌 동시에 추구해야 하는 목표이고 경제개 발과 민주화가 서로 긍정적으로 기여하는 선순환의 구조를 지닌다. 이러한 유형은 자유로운 언론과 역동적 시민사회 그리고 발하고 효율적인 시장경제와 민주적 가너번스 제도 등이 특징으로 나타난 다. 90 년대 이후 민주화의 단계로 접어든 한국과 대만, 그리고 최근 민주주의가 크게 진전된 것으로 평가받고 있는 인도네시아가 이에 가까운 것으로 볼 수 있다.

단순화한 두 가지 유형 이외에 '경제개발 없는 민주화'와 경제개발과 민주주의 모두 이루지 못한 실패국가(failed state) 유형도 생각해 볼 수 있다.

'경제개발 없는 민주화'는 형식적 민주화를 이루었지만 만성적이고 구조적인 가난을 극복하지 못 해 민주화가 형해화되고 민주화와 경제개발 모두 지체 또는 후퇴하는 악순환되는 특성을 보인다. 아 시아에서는 필리핀이 이런 경우에 해당한다. 60 년대까지 아시아의 선진국이었던 필리핀은 마르코스 독재를 계기로 침체되었지만 80년대 중반 민주화를 계기로 새로운 계기를 맞이하였다. 다당제와 자유 로운 선거, 언론자유 등 민주주의의 기본적 제도가 구축되어 있지만 그러나 이후 경제정책의 연이은 실패로 대다수의 국민이 여전히 가난의 굴곡을 벗어나지 못한 상태에 있다.

마지막으로 실패국가는 아시아에서 버마(미얀마)와 북한 처럼 경제개발과 민주주의로 이룩하지 못 해 국민 대다수가 절대빈곤과 기본적 자유를 누리지 못하는 상황에 처한 경우를 말한다.

어떠한 유형에 속하느냐에 따라 국가와 시민사회가 처한 환경과 역할이 달라진다. 국가의 역할이 라는 관점에서 보면 개발독재는 비민주적 권위주의 정부이지만 경제개발에 효율적이었지만 그리고 민주적 개발은 국가가 민주적이면서 동시에 경제개발도 성공적으로 수행한 경우라고 말할 수 있다. 
경제발전과 민주화에 따른 사회발전 모델

\begin{tabular}{|c|c|c|}
\hline 민주화 경제발전 & 성공 & 실패 \\
\hline 민주적 정부 & 민주적 개발 & 경제개발없는 민주화 \\
\hline 비민주적 정부(독재) & 개발독재 & 실패국가 \\
\hline
\end{tabular}

위에서 분류한 네 가지 유형에 따르면 한국은 80년대 중반까지 개발독재, 그 이후 과도기를 거쳐 김영상 문민정부를 거쳐 김대중, 노무현 정부로 들어오면서 민주적 개발 방식으로 전환한 것으로 평 가할 수 있다. 최근 표현의 자유 후퇴와 양극화 심화로 인해 이러한 선순환 모델에 우려가 높아지고 있지만 다른 국가와의 비교 및 장기적 경향성에서 볼 때 이러한 모델에 속한다고 할 수 있다.

\section{4. 한국의 사회발전 - 해외원조의 역할}

앞에서 언급했듯이 부산총회를 계기로 한국의 성공적인 경제개발에 원조가 어떤 역할을 하였느냐 에 대한 논의가 활발하게 전개되고 있다 그리고 한국개발연구원(KDI)이 주도하는 지식공유사업 $(\mathrm{KSP})$ 의 일환으로 한국개발경험을 모듈화하여 개도국에 소개하는 작업이 활발하게 이루어지고 있 다. $\mathrm{KDI}$ 는 $\mathrm{OECD}$ 등 각종 국제회의에서 한국의 개발경험과 원조의 역할을 발표하면서 한국을 파리 선언에서 강조하는 주인의식, 성과관리 및 책무성 원칙에 따른 모범사례라고 발표한 바 있다. 이를 언론에서는 '한국개발 모델 비법 전수', '정책한류'란 표현으로 부각시키고 있으며 과거 '한강의 기적 표현처럼 한 세대 만에 가난한 수원국에서 공여국으로의 발전을 성공신화로 부각시키고 있다.

이러한 발표에서는 거의 대부분 한국의 발전경험을 소개하면서 대표적으로 새마을운동, 경부고속 도로 그리고 포항제철 등의 성공사례로 소개하면서 중앙 정부의 강력하고 효율적인 경제정책 수립과 집행이 경제개발 성공의 핵심이었음을 강조하고 있다. 물론 객관적 통계를 볼 때 한국 정부가 당시 $\mathrm{ODA}$ 를 효율적으로 잘 활용하여 경제발전의 촉매 또는 지렛대로 활용한 것은 잘 알려진 사실이다. 그러나 이러한 한국의 개발경험에 대한 경제중심적, 국가관료 중심적 접근은 개발독재에 대한 옹호 또는 미화로 이어지면서 국내 및 국제 시민사회의 우려와 비판을 불러 일으키고 있다.

이러한 우려와 비판은 크게 한국 사회발전 모델의 보편성과 지속가능성 측면에서 제기되고 있다, 여기서 보편성이란 과연 그러한 모델을 국내외적 정치경제 환경이 판이하게 다른 가난한 개도국에도 적용할 수 있는가라는 적용가능성, 그리고 지속가능성이란 과연 금융경제위기가 반복 심화되는 오늘 날의 신자유주의 세계화 시대에도 그러한 발전전략이 지속적으로 가능할 것인가의 문제를 말한다.

보편성과 관련하여 가장 자주 지적되는 비판은 한국이 수출주도 경제성장 정책을 도입해서 가난에 서 극복하던 60-70년대의 국내외적 정치 및 경제환경과 오늘날의 환경은 전혀 다르다는 것이다. 따 라서 당시 한국의 정부가 했던 역할과 해외수출지향 산업화 전략을 오늘날 개도국의 다른 나라가 그 
대로 실행하는 것은 무리라는 것이다. 말로는 one-size-fit-for-all을 거부하면서 사실은 한국의 경 험을 일반화하고 이식하려는 오류를 범하고 있다는 것이다.

한편 지속가능성 관련하여서는 오늘날 한국사회가 겪고 있는 사회적 위기와 한국형 개발모델과의 연관성에 대한 비판적 지적이 제기되고 있다. 각종 성장률 통계로 보여주는 양적 경제 성장이면에 악화되는 사회적 위기, 즉 $\mathrm{OECD}$ 최저 출산률과 최고의 자살률, 최장 노동시간 등으로 대표되는 사 회적 위기는 이른바 수출지향적 압축적 경제성장 중심의 사회발전 모델의 휴유증 또는 부작용 이라 는 것이다. 경제성장을 통해서 어떤 사회발전을 이룰 것인지 또는 공동체의 삶의 질에 대한 고민 없 이 경제성장 자체가 목적이 되어버린 성장지상주의가 가져오는 사회적 폐혜를 볼 때 오늘날 세계적 금융위기 하에서 과연 과거의 개발모델이 지속적으로 가능할 지에 대한 의문이 커지고 있다.

$\mathrm{OECD}$ 에서 말하는 지식공유사업(KSP)은 특정 정책이 어떤 국내외적 조건하에서 설정한 목표를 어 떻게 달성했는지를 분석하고 그 과정에서 얻은 교훈을 공유하는 것이 주된 목적이다. 특히 다양한 조건 하에서 시행된 여러 정책을 비교 분석함으로써 새로운 정책 개발시 시행착오를 줄여 정책의 효 과성을 높이는데 기여하고자 한다. 그러나 한국의 현재 KSP 사업은 반성과 교훈 보다는 과거 정책 홍보의 정치적 성격이 강해서 분석의 객관성과 신뢰성에 적지 않은 의문이 제기되고 있다.

국제적으로 한국이 발전의 모델로 주목받는 것은 단순히 경제성장 때문이 아니라 경제성장이 시민 사회의 발전 즉 시민사회 성장과 민주화와 함께 이루어졌고 그 결과 전반적인 인권 신장이 이루어졌 기 때문이다. 즉 앞에서 언급했던 개발독재에서 시민사회 성장과 민주화를 거쳐 민주적 개발 모델로 의 전환이 한국 개발모델의 핵심이라고 할 수 있다.

$\mathrm{KDI}$ 가 국제적으로 소개하는 한국의 개발모델에서는 경제성장 과정에 있었던 노동자의 희생, 탈이 농 급속한 도시화 과정에서의 농촌 공동체의 파괴와, 환경파괴, 인권 탄압과 언론탄압 등은 경시하거 나 언급조차 하지 않고 있다. 이른바 개발독재의 부작용 또는 부정적 측면을 외면하여 시민사회 또는 민주화의 역할을 무시 또는 평가절하하고 있다.

잘 알려졌듯이 군부독재 하 민주화 운동 과정에서 많은 사람들의 희생이 있었고 이들의 선도적 노 력이 한국의 민주화에 큰 기여를 하였다. 이 과정에서 당시 시민사회 특히 개신교와 천주교를 통해 국내의 노동, 농민 및 시민사회 지도력 양성에 사용된 해외의 민주화운동 지원기금의 역할에 대해서 도 주목할 필요가 있다. 군사독재 하에서 사적으로 이루어진 해외원조에 대한 실증적 연구가 없어 정 확한 통계로 뒷바침 할 수 없지만 당시의 민주화 운동 기록에 따르면 상당액의 민간 지원금이 당시 사회운동 발전의 밑거름이 되었다고 추측할 수 있다. ${ }^{3)}$

즉 미국과 서방 국가의 ODA가 초기 경제개발 단계에서 촉매의 역할을 했다면 ODA 또는 민간재원 형태(Private Development Assistance, PDA)로 국내에 도입된 원조는 60년대부터 80년대까지 사회 개발과 시민사회의 리더십 역량강화에 많은 기여를 했고 이는 80년대 후반 이후 민주화로 결실을 맺

3) 이와 관련하여 한국국제개발협력시민사회포럼(KoFID)의 원조와개발효과성 및 인권주제 분과는 원조와 사회개발 및 민 주화의 연관에 대한 실증적 자료수집 및 정리를 하여 부산 세계개발원조총회 전에 발표 예정이다. 
는데 큰 역할을 했다고 볼 수 있다. 즉 이를 정식화하자면 한국의 사회발전 또는 민주적개발 모델은 정부주도의 경제개발 $\mathrm{ODA}$ 와 사회발전 특히 민주화의 원동력된 $\mathrm{ODA}$ 일부와 $\mathrm{PDA}$ 를 토대로 성립되었 다고 할 수 있다. 즉 당시 해외로부터 사회운동과 시민사회 재정 지원이 없었다면 한국의 민주화는 지체되었거나 오늘날과 다른 형태로 이루어졌을 가능성이 높았다고 할 수 있다.

한국의 사회발전 특히 해외원조와 한국 사회발전의 관계를 어떻게 이해하느냐는 한국의 해외 개발 원조의 내용과 방향에 중요한 시사점을 던져준다. 의식적이든 무의식적이든 한국 정부와 시민사회가 추진하는 해외 개발원조 사업의 내용은 한국의 개발 경험에 대한 해석의 영향을 받을 수 밖에 없기 때문이다. 즉 ‘한국형 개발경험’의 핵심을 경제성장과 사회발전 균형적 발전 즉 시민사회의 성장과 민주화를 토대로 한 민주적개발로 이해한다면 '한국형 원조모델'의 핵심적 내용 또한 수원국의 경제 개발과 시민사회 및 민주화 지원이 될 가능성이 매우 높다고 할 수 있다.

\section{5. 한국의 사회발전과 개발원조 모델}

원조를 통한 국제개발협력에는 다양한 모델과 유형이 있는데 현재 한국의 시민사회에서 논의되는 유형은 크게 다음의 세가지로 구분해 볼 수 있다. 첫째 크게 더 많은 양의원조를 주장하는 "More Aid', 둘째 양보다 더 나은 양질의 원조를 주장하는 'Better Aid' 그리고 세째 기존의 원조모델에 대 한 대안을 모색하는 대안적 원조 'Alternative Aid'로 구분해 볼 수 있다. 이러한 M-B-A 모델은 앞 서 서술한 한국의 개발 즉 사회발전 경험에 대한 이해와 밀접한 관련이 있다.

첫째 'More Aid' 유형은 기존의 경제중심 사회발전 모델과 연관이 많은데 이러한 유형에서는 원조 의 양을 늘려 가난 퇴치와 소득 증대를 도모하고 국가적으로는 국민총생산(GNP)의 증대하는 것을 중요시 한다. 현재 한국 개발원조의 대다수가 이 모델을 따르고 있다. 새마을 운동, 주민소득 증대사 업, 수출주도 산업을 위한 인프라 구축 등 원조를 통한 경제적 역량 강화가 중요하게 간주된다.

둘째 'Better Aid' 유형은 경제 뿐만 아니라 시민사회 등 사회발전을 강조하는 모델로 원조의 양보 다는 질 즉 원조의 효과성을 중시한다. ${ }^{4)}$ 경제성장과 민주적 거버넌스를 통한 사회 정치 문화적 발전 을 동시에 도모한다. 이 유형은 시민사회의 권력감시 역할 강화, 독립적인 언론과 의회 및 정당 등 민주적 정치제도의 강화, 사법부의 독립 등 국가적 차원의 민주적 거버넌스 강화를 강조한다. 이러한 모델은 사회발전을 단순히 경제적 수치와 통계로 환원하지 않고 인간발전지수나 최근 국제기구 특히 $\mathrm{OECD}$ 가 검토하고 있는 행복지수나 웰빙지수 등 보다 포괄적인 사회발전 지수를 중시한다. 민주적 개발과 친화성이 있는 이 모델은 경제개발과 사회개발을 동시에 강조하고 시민사회의 역할 및 민주 주의의 강화를 주장하는 유형이다. 한국의 경우 이 모델에 따르면 과거청산, 시민사회의 권력감시 역 할, 부패방지와 청렴위원회(현 권익위원회), 국가인권위원회 등 민주적 거버넌스를 증진하는 다양한

4) BetterAid는 원조효과성을 위해 2008년 결성된 국제 네트워크의 명칭으로 국제 NGO의 지향을 상징적으로 보여주고 있 다. www. betteraid.org 
제도 등이 지식공유의 주된 내용이 된다.

셋째 'Alternative Aid' 유형은 원조를 통해 기존의 경제 사회 발전 모델을 극복하는 새로운 사회 발전을 모색하고자 한다. 원조의 필요성을 인정하고 활용하지만 원조를 통해 기존의 공동체적 삶이 신자유주의적 시장논리에 편입되는 것을 경계하며 공동체의 자연 및 문화적 환경과 조화를 이루면서 경제적으로 자립하는 사회발전 모델을 추구한다. 이러한 유형은 국가 차원보다는 지역 차원에서 주 로 시도되고 있는데 구체적인 사례로는 도동직거래운동, 공정무역, 기본소득운동, 생태마을이나 생 태도시 또는 인권도시와 같은 대안공동체운동, 협동조합운동, 지역화폐운동 등을 들 수 있다.

이러한 $\mathrm{M}-\mathrm{B}-\mathrm{A}$ 세가지 모델의 관점에서 볼 때 현재 한국정부와 상당수의 시민사회단체는 한국의 개발경험을 바탕으로 더 많은 원조를 주장하고 있고 소수의 시민사회단체가 한국의 개발경험에 대한 비판적 해석을 바탕으로 양보다는 질을 강조하는 더 나은 원조 그리고 더 나아가 대안적 원조를 고민 하고 있다고 볼 수 있다.

\section{6. 한국의 $\mathrm{ODA}$ 정책에 대한 함의와 제언}

앞에서 설명했듯이 지금까지 한국의 개발원조 정책은 경제적 측면에 치우쳐 민주화와 사회개발 등 한국개발경험의 다양한 측면이 제대로 반영되지 못하였다. 부산 총회를 계기로 한국정부와 시민사회 는 한국의 개발 경험에 대한 균형 잡힌 해석과 분석을 바탕으로 국제개발협력 정책을 개발하고 추진 할 필요가 있다. 이와 관련하여 한국의 경제성장과 민주화에 대해 언급한 지난 9월 이명박 대통령의 유엔총회 연설은 단순한 외교적 언사가 아니라 적극적이고 구체적인 정책으로 뒷받침될 필요가 있 다. 5) 이러한 인식을 바탕으로 보다 바람직하고 균형잡힌 ODA 정책을 위해 몇 가지 제안을 하고자 한다.

5) 지난 9 월 유엔총회에서 이명박 대통령의 연설은 한국의 개발모델에 대한 균형잡힌 시각을 담고있어 국제사회의 주목을 받았다. 그러나 이러한 대통령의 관점과 $\mathrm{KSP}$ 의 구체적인 내용과는 아직 큰 간격이 존재하고 있다. "한국은 20년간 유 엔 회원국으로서 유엔의 정신과 가치를 구현하는데 최선을 다해 왔습니다. 국제사회의 빈곤퇴치와 지속가능한 개발, 인 권증진과 민주화, 국제평화유지 등의 분야에서 적극적인 역할을 수행하고 있습니다. 한국은 전쟁과 가난을 겪고 세계 최빈국의 위치에서 출발하여 극적으로 경제발전과 민주화를 이루었으며, 이는 유엔이 표방하는 민주주의, 인권, 개발의 가치를 가장 모범적으로 구현한 사례라고 할 수 있을 것입니다 이제 한국은 그동안 국제사회로부터 받은 것 이상으로 보답하고자 합니다. 도움을 꼭 필요로 하는 곳에 가장 알맞은 도움을 주고, 국제사회가 당면한 도전들을 극복해 나가는 데 있어 건설적인 역할을 할 수 있도록 유엔과 적극 협력해 나갈 것입니다.

민주주의는 지속가능한 국가발전의 토대이기도 합니다. 한국의 경우, 경제성장이 민주화를 진전시켰고, 민주화는 다시 경제성장을 촉진했습니다. 21세기 세계화 정보화 시대에는 경제수준과 상관없이 민주화는 거스를 수 없는 대세가 되었 습니다. 나는 민주주의의 활력이 경제 발전의 원동력이 될 것으로 믿습니다. 개발도상국이 민주주의와 경제성장을 동시 에 추구할 수 있도록 돕는 것이야말로, UN의 역할이라고 생각합니다.

의장님, 민주주의와 시장경제는 인간의 자유, 행복의 가치와 더불어 개인의 더 나은 삶을 향한 욕구를 충족시키는데 기 여하였습니다. 하지만 지금 고도의 자유시장경제에서 나타나는 빈부의 격차 현상은 자본주의 시스템의 자기반성과 보다 공익적인 책임을 요구하고 있습니다.

...

유엔이 추진하고 있는 「새천년개발목표(MDGs)」역시 선진국과 개발도상국의 공생발전을 추구하는 중요한 어젠다입니 다. 한국정부는 ‘새천년개발목표」가 추구하는 국제사회의 개발협력 노력에 적극 동참할 것입니다. 2015년까지 ODA 규 모를 현재의 두 배 이상으로 확대하는 계획을 착실히 이행하면서 우리의 개발경험을 바탕으로 개도국 스스로 성장할 수 
첫째, KDI가 2004년부터 추진하고 있는 경제성장 중심의 지식공유사업(KSP)에 사회개발과 민주 화 및 시민사회의 역할을 적극적으로 포함시켜야 한다. 특히 한국의 개발경험을 산업화와 민주화 두 축을 기반으로 보다 균형있게 분석 소개할 필요가 있다. 이와 관련하여 한국해외원조단체협의회(해 원협)은 부산 세계개발원조총회에 임하는 한국정부에 대한 정책제안에서 “한국정부는경제개발중심의 지식공유프로그램(KSP) 내용에 한국의 민주화, 시민사회의 정책감시 및 사회개발 경험을 포함해야 한다."고 주장한 바 있다. ${ }^{6)} \mathrm{KDI}$ 가 경제개발 경험을 모듈화하듯이 KOICA는 관련 기관과의 협력하에 사회개발과 민주화 중심의 경험을 모듈화하는 역할을 할 필요가 있다. 물론 이를 위해서는 KOICA의 정책연구 기능을 보다 강화할 필요가 있다. 특히 사회개발과 민주화에 대한 시민사회의 역할에 대한 객관적이면서도 적극적인 평가가 필요하다. 더 나아가 이 과정에서 경제성장과 민주화 및 사회발전 과의 관계에 대한 보다 깊이 있는 연구를 통해 한국의 경험을 보편화 할 수 있는 이론적 근거를 만들 필요가 있다.

둘째로 이렇게 정리된 내용을 KOICA가 진행하고 있는 개도국 공무원 연수 및 ODA 관련 교육에 체계적으로 반영하여야 한다. 더 나아가 KOICA와 민간단체의 해외봉사단 파견 교육에도 적극적으로 반영할 필요가 있다. 한국의 개발경험을 국제사회 특히 유엔이 추구하는 가치이자 프레임인 민주주 의, 개발, 인권 등 보편적 개념을 적극 도입하여 한국 개발경험에 대한 아전인수적 해석을 탈피하고 한국의 개발경험에 대한 시각차이를 줄이는 것이 매우 필요하다. 특히 한국정부가 중점적으로 보급 하고 있는 '새마을 운동'을 파리선언과 같은 국제사회의 보편적 규범과 개념에 입각하여 비판적으로 분석 평가하여 현지 상황과 맥락에 부합하는 개발정책으로 발전시킬 필요가 있다. 그리고 광주광역 시가 추진하고 있는 인권도시 모델 또한 개도국 지방정부와의 협력사업으로 추진해 볼 필요도 있다.

셋째, 국제개발협력 사업에 민주화를 반영하는 사업을 개발 실시할 필요가 있다. 민주화는 시민사 회 역량과 리더십 강화, 민주적 거버넌스(Democratic Governance), 투명성과 책무성 증진, 인권보 호와 증진 제도, 법치 등 다양한 형태의 정책으로 반영된다. 현재 KOICA의 7대 중점사업 영역 중 민 주화와 가장 관련이 많은 공공행정(governance)과 범분야(cross-cutting issues)에서 한국의 민주 화와 민주적 거버넌스 경험을 적극적으로 반영시키는 것이 필요하다.

그러나 대다수의 개발지원 대상국가에서 민주화나 인권이 여전히 정치적으로 민감한 이슈임을 감 안할 때 정부기관이 직접 지원하는 것 보다는 상대적 독립성을 지닌 시민사회단체나 공익 민간재단 이 이를 수행하는 것이 더 효과적일 수 있다. 그러나 현재 이러한 사업을 수행할 수 있는 국내 시민 사회의 전문적 역량은 매우 취약하여 이에 대한 각별한 관심과 지원이 요구된다. 특히 한국정부의 지 원사업을 포함한 다양한 국제개발사업 과정에서 발생할 수 있는 부정부패를 감시 및 고발하고 정책 대안을 제시하는 현지 시민사회의 역할을 강화하는 사업을 지원할 필요가 있다.

있는 역량을 배양하도록 도울 것입니다. 이러한 「새천년개발목표」에 부응하여, 오는 11월 한국의 부산에서 개최되는 세 계개발원조총회(Fourth High Level Forum on Aid Effectiveness: HLF-4)가 국제개발협력 환경의 변화에 부응하는 새 로운 개발협력 패러다임과 파트너십을 도출하는 계기가 될 것으로 기대합니다."

6) www.ngokcoc.or.kr 
이러한 상황에서 정부가 지원하는 민주화 관련 재단을 보다 적극적으로 활용하는 것이 필요하다. 현재 민주주의 관련하여 정부가 설립한 재단으로는 광주 5.18 기념사업회와 서울의 민주화기념사업회 두 기관이 있다. 그러나 두 곳 모두 국제적 차원의 민주주의 지원 사업 실적은 미미한 편이다. 광주 의 5.18 재단이 재정지원 사업을 포함 아시아 민주주의 지원사업을 다양한 방식으로 실시해왔고 민 주화기념사업회는 해외의 민주주의 국제협력 기관 현환 등 기초적인 조사연구를 수행한 것 이외에 예산과 인력 부족으로 아직 구체적인 사업을 착수하지 못하고 있다. KOICA의 사업에 민주화의 가치 와 원칙을 반영하는 것도 중요하지만 미국처럼 민주주의를 전담하는 재단을 설립하는 것도 고려할 필요가 있어 보인다. ${ }^{7)}$

한편 시민사회와 국내의 정부 재단을 통한 지원 이외에도 유엔 민주주의기금(UNDEF)을 통한 민 주주의 적극적 지원의 증대를 고려할 필요가 있다. 한편 일부 지역에서 민주주의가 지닌 정치적 민감 성을 고려할 때 유엔을 통한 지원은 정당성 측면에서 장점을 지닌다. 2011년 현재 한국은 누적합계 100 만불 기부로 전체 기부 국 중 11 위이다. ${ }^{8)}$ 주목할 만한 사항은 아시아에서 인도, 일본, 카타르가 상위권을 차지하고 있다는 것이다. ${ }^{9)}$ 세계 최대의 민주주의 국가인 인도, 중동의 민주주의 선두주자 인 카타르가 유엔을 통한 민주주의 증진을 국제협력에서 민주주의를 주요 의제로 삼고 있다는 점은 아시아의 선도적 민주주의 국가로 평가 받아온 한국에 시사하는 바가 크다.

\section{II. 결 론}

부산총회는 국제적으로 새로운 국제개발협력 패러다임을 모색하고 국내적으로 한국의 개발원조 정책과 사업을 국제적 기준에 부합하게 개혁하고 중장기적으로 한국형 원조패러다임을 모색하는 역 사적 계기이다. 이 계기를 효과적으로 활용하기 위해서는 개발원조를 경제적 정치적 이해관계가 아 닌 인권과 민주주의와 같은 보편적인 가치와 규범에 따라 이해하고 실천하는 것이 요청된다. 특히 이 과정에서 한국정부와 시민사회는 비판적 협력관계를 유지하면서 생산적인 파트너십을 구축할 필요가 있다. 이를 위해서는 한국의 개발경험에 대해 경제성장 만이 아닌 시민사회와 민주화를 포함하는 균 형있는 접근과 해석이 매주 중요하다.

부산총회를 계기로 국제개발협력의 정책 담론이 원조효과성에서 개발효과성으로 심화 확대되고 있다. 그리고 개발효과성에 대한 논의에서 주의의식, 책무성, 효과적인 개발제도 구축(Effective Institution)

7) 미국식 모델에 따르면 개발은 USAID, 민주주의는 National Endowment for Democracy(NED)로 기능적으로 구분되어 있다. 그러나 민주주의는 두 기관 모두 공유하는 비전이자 원칙에 해당한다. NED는 철저하게 초당파적으로 운영되어 특정 정당의 정책의 과도한 영향으로부터 상대적 자율성을 지키면서 운영되고 있다.

8) http://www.un.org/democracyfund/

9) 2011년 9월 21일 현재 누적금액 기준으로 인도는 미국에 이어 2위, 3위 독일에 이어 일본과 카타르가 4, 5위를 차지하 고 있다. 
등 민주적 거버넌스는 관련 핵심 이슈들이 중요하게 다루어지고 있다. 이런 맥락에서 최근 민주주의 와 인권의 후퇴 논란에도 불구하고 지금까지 한국 사회가 성취한 민주적 거버넌스의 경험은 국제사 회와 공유할 가치가 있는 소중한 자산이다. 이러한 자산을 가난 극복과 민주화의 과제를 안고 있는 개도국과 나누는 것은 부산총회를 개최국 정부이자 시민사회로서 책무이자 과제이다. 


\section{참고문헌}

\section{1. 국내문헌}

이성훈 “국제개발협력과 인권-부산 OECD 원조효과성회의와 한국의 역할” (국제개발협력 2011 No. 1)

이성훈, "G20 정상회의와 개발 - 절반의 성공이자 실패"〈ODA Watch 뉴스레터 제47호〉 ( 2010 년 11월 16일)

이성훈, “지구화 시대의 개발 NGO”, 〈지구화 시대의 한국시민사회〉 (서울, 아르케 2011)

민주화운동기념사업회 편 “민주주의 국제협력기관 : 지구민주화와 공공외교의 지형도” (리북,

2010)

유해정, “인권과 발전: HRBA 모델의 비판적 고찰” 〈경희대학교 NGO 대학원 글로벌 거너번스 전공 석사학위 논문> (경희대학교 NGO 대학원, 2009)

한국인권재단 인권아카데미 벼리, “인권에 기반한 개발과 기업의 역할” 〈세미나 자료집〉 (한국 인권재단 인권아카데미 벼리, 2011)

한국인권재단 ODA 연구팀, "ODA 정책이 수원국의 인권에 미치는 영향” (2007년도 국가인권위

원회 연구용역 보고서) (한국인권재단 2007)

ODA Watch, “국제개발협력 선진화 방안인가, 한국화 방안인가?" ODA Watch 뉴스레터 제47

호, 2010년 11월 16일

$\mathrm{ODA}$ 워치 $\mathrm{DAC}$ 팀, "연재 1 호: 제 4 차 부산 원조효과성 고위급회의와 시민사회의 역할" $\mathrm{ODA}$

Watch 뉴스레터 제48호, 2010년 12월 31

김은미, 김진경 “ $\mathrm{OECD} / \mathrm{DAC}$ 거버번스 네크워크(GOVNET) 논의동향과 대응을 위한 정책과제” 국제개발협력 (서울, KOICA, 2010. No. 3)

김 인, "HLF4 준비 공동연구 진행상황 보고-Catalyzing Development: A New Vision for Aid”, 국제개발협력 (서울, KOICA, 2010. No. 3)

이련주 “국제개발협력 선진화 방안” 국제개발협력 (서울, KOICA, 2010. No. 4)

이현주 “남남협력의 효과성과 과제: HLF4 및 글로벌 차원의 정책방안을 중심으로”, 국제개발협

력 (서울, KOICA, 2010. No. 3)

정우진 “한국형 개발협력모델” 국제개발협력 (서울, KOICA, 2010. No. 1)

한재광 “지구촌 빈곤감축을 위한 시민사회의 노력” 국제개발협력 (서울, KOICA, 2010. No. 4) 김신, 양영미 역「인권을 생각하는 개발 지침서(Development As a Human Rights)」(서울;후 
마니타스, 2010)

\section{2. 국외문헌}

BASPIA, 인권에 기반한 개발협력에 대해 자주 물어보는 질문들(FAQ) Frequently Asked Questions on a Human Rights-Based Approach to Development Cooperation, (유엔 인권최고대표사무 소, UN OHCHR, 2006)

Better Aid, Development effectiveness in development cooperation: a rights-based perspective BetterAid (Oct 2010)

Better Aid, Making development cooperation just: Governance principles and pillars (Dec. 2010) 